\title{
Use of shelters and marking sites by Lontra longicaudis (Olfers, 1818) in lotic and semilotic environments
}

\author{
Lívia Bertolla Santos ${ }^{1,2}$ \& Nelio Roberto dos Reis ${ }^{1}$ \\ ${ }^{1}$ Graduate Programme in Biological Sciences (Zoology), Londrina State Universtity - UEL, \\ Rod. Celso Garcia Cid, PR 445, Km 380, CP 6001, CEP 86051-980, Londrina, PR, Brazil \\ ${ }^{2}$ Corresponding author: Lívia Bertolla Santos, e-mail: liviabertolla@yahoo.com.br
}

SANTOS, L.B. \& REIS, N.R. Use of shelters and marking sites by Lontra longicaudis (Olfers, 1818) in lotic and semilotic environments. Biota Neotrop. 12(1): http://www.biotaneotropica.org.br/v12n1/en/ abstract?article+bn02512012012

\begin{abstract}
The Neotropical otter Lontra longicaudis (Olfers, 1818) (Carnivora: Mustelidae) is a semi-aquatic species spread throughout Central and South America, except Chile. It uses cavities on the river banks or spaces amidst dense vegetation as shelter and defecates in conspicuous places as a means of territorial marking. The study was conducted between April 2008 and March 2009, aiming to compare and correlate the frequency of shelter use and marking by the otters, considering vertical vegetation cover, height, distance, disturbance degree and type of structure/substrate factors, in a lotic environment (Sapé stream, São Paulo state, Brazil) and a semi-lotic environment (Canoas I hydroelectric reservoir, Paranapanema Valley, São Paulo and Paraná states, also in Brazil). The aim was to compare and correlate the frequency of shelter use and marking by the otters, considering factors like vertical vegetation cover, height, distance, degree of disturbance and type of structure/substrate in two areas. It was evidenced that the otter's shelters show visual protection differences in each environment. Around the reservoir, the otters make greater use of areas with higher degrees of disturbance and are selective about the type of shelter structure. Along the stream, the otters favor areas with greater vegetation cover to demarcate. Our results warrant emphasis that other abiotic, biotic or density dependent factors (population number and intra or interspecific competition, for example) may be responsible for the otters' different choice of sites used for shelters and markings in the two environments but they were not identified in this study. Moreover, the different number of samples obtained in each location may have harmed the statistical analyses. However, based on the results, we were able to conclude that the species is able to adapt to the altered environment of the reservoir, using shelters and depositing markings according to the imposed environmental conditions and, whenever possible, it takes advantage of the facilitated food capture offered by environment. Nevertheless, the otters still present some dependence on areas with preserved vegetation, where they find sites with better shelter and marking conditions. Keywords: lotic environment, Neotropical otter, scent marking, semilotic environment, shelter sites.
\end{abstract}

SANTOS, L.B. \& REIS, N.R. Uso de abrigos e locais de marcação por Lontra longicaudis (Olfers, 1818) em ambientes lótico e semilótico. Biota Neotrop. 12(1): http://www.biotaneotropica.org.br/v12n1/pt/ abstract?article+bn02512012012

Resumo: A lontra neotropical Lontra longicaudis (Olfers, 1818) (Carnivora: Mustelidae) é uma espécie semiaquática distribuída em toda a América Central e do Sul, exceto no Chile. Utiliza cavidades na margem do rio ou espaços entre a vegetação densa como abrigos e defeca em locais conspícuos como função de marcação territorial. O estudo foi realizado entre Abril de 2008 a Março de 2009 e teve como objetivo comparar e correlacionar a frequência de utilização dos abrigos e sítios de marcações das lontras com fatores de obstrução foliar vertical, altura, distância, grau de distúrbio e tipo de estrutura/substrato em um ambiente lótico (riacho Sapé, estado de São Paulo, Brasil) e um semilótico (reservatório da hidrelétrica de Canoas I, Vale do Paranapanema, estados de São Paulo e Paraná, Brasil). Constatou-se nesse estudo que os abrigos das lontras apresentaram diferenças na proteção visual em cada ambiente; que, no reservatório, utilizam mais intensamente áreas com maior grau de distúrbio e são seletivas quanto ao tipo de estrutura dos abrigos; enquanto, no riacho, as lontras demarcam preferencialmente áreas com maior obstrução vegetal. Nossos resultados permitem-nos enfatizar que outros fatores abióticos, bióticos ou denso-dependentes (número populacional e competições intra e interespecífica, por exemplo) podem ser responsáveis pela diferença na escolha das lontras pelos locais usados como abrigos e para marcações entre os dois ambientes, porém, não foram identificados nesse estudo. Além disso, a diferença no número de amostras obtidas em cada ambiente pode ter prejudicado as análises estatísticas. Conclui-se que a espécie mostra plasticidade ao ambiente alterado do reservatório, utilizando abrigos e depositando marcações conforme as condições impostas, obtendo vantagens, sempre que possível, das facilidades em captura de alimento oferecidas por este ambiente. No entanto, as lontras ainda apresentam certa dependência por áreas de vegetação preservada, onde encontram melhores condições de abrigo e marcação.

Palavras-chave: ambiente lótico, lontra Neotropical, marcação odorífera, ambiente semilótico, abrigo. 


\section{Introduction}

The Neotropical otter Lontra longicaudis (Olfers, 1818) (Carnivora: Mustelidae) is a semi-aquatic species widely spread throughout Central and South America, from Mexico to Uruguay and Argentina, except for Chile (Eisemberg \& Redford 1999). It can be found in almost the whole Brazilian territory, except in the drier areas of the northeast region (Fonseca et al. 1994).

Its habitat includes lakes, rivers, wetlands, marine shores associated with coastal lagoons (Rosas et al. 1991), ample riparian vegetation (Bertonatti \& Parera 1994, Redford \& Eisenberg 1992) and abundant potential den sites (Soldateli \& Blacher 1996).

Otters are animals in the top of the food chain and for this they are sensitive to changes in their habitat. Moreover, they are dependent of a terrestrial environment adjacent with watercourse and can be damaged due to modification in the water's quality and in the margins caused mainly for human activities (dragging, draining, construction of dikes, commercial fishing, exclusion of riparian wood and chemical and organic pollution) (Rosas 2004).

The species is listed as endangered in the Appendix I of the Convention on International Trade of Endangered Species of Wild Fauna and Flora (CITES) (Convention... 2008), it is included in the "data deficient" of the International Union for the Conservation of Nature (IUCN) (International... 2010) and it is also considered "near threatened" in Brazil according to Red Book of the Brazilian Endangered Fauna (Chiarello et al. 2008).

Its shelters or dens are used for resting between activity periods, sleeping, as haven in bad weather, to give birth and rear offspring. They are usually located in banks covered by larger vegetation, greater vertical vegetation cover (VVC), because these environments provide protection from rain, disturbance and other animals (Waldemarin \& Colares 2000). Dens are usually located in higher banks, far from the water level, due to the lower flood risk (Pardini \& Trajano 1999, Uchôa et al. 2004). Although the otter seems to avoid areas with large concentration of humans (Blacher 1992), Pardini \& Trajano (1999) maintained in their work that the otters use areas where forest had been cut and or human disturbance was relatively intense with the same frequency that they use pristine areas; and that the effects of human activities on the sheltering behavior of otters may depend on the size of the disturbed area and existence of preserved areas of appropriate size nearby. The structures of the shelters differ among the species and the kind of aquatic habitat (Chanin 1985) and can be classified as cavity among stones, cavity under tree roots, limestone dissolution cavity, cavity in rocky wall, space among vegetation and excavated burrows (Pardini \& Trajano 1999).

Marking sites are conspicuous points in the environment, such as rocks, trunks, roots and banks (Parera 1993, Rocha \& Sekiama 2006), where faeces and anal secretion are continuously deposited as a means of territorial marking. The markings of other otter species as Lontra provocax (Thomas, 1908), Lutra lutra (Linnaeus, 1758) and Lontra canadensis (Schreber, 1777) are usually found in areas with less concentrated vegetation, because their visual and scent markings can be better perceived by other individuals (Madsen \& Prang 2001, Medina-Vogel et al. 2003). However, individuals of the L. longicaudis species, studied by MacDonald \& Mason (1987) and Spinola \& Vaughan (1995), most often defecate in areas with greater vertical plant cover. The marking sites are commonly located in places with little or no disturbance (Gori et al. 2003), on high banks and far from the water level (Pardini \& Trajano 1999, Uchôa et al. 2004).

Factors such as height and distance from the water level, type of structure or substrate, degree of marginal vegetation coverage and degree of disturbance can influence on how often the otters use the shelters and marking sites (Pardini \& Trajano 1999). There is, for now, little information available on the use of shelters and markings by Lontra sp. in changed environments by damming up watercourse. These data are limited to works of Pedroso et al. (2004) with Lutra lutra around storage dams of some hydroelectric powers in Portugal and others with L. longicaudis: Louzada-Silva et al. (2003) along Paranoá lake in Brasilia, Federal District of Brazil; Kasper et al. (2004) in an area of implantation of a hydroelectric in Taquari Valley, southern Brazil; J. Quadros (2006 unpublished data) in a hydroelectric on Iguaçu river in Paraná state, southern Brazil. However, this information is needed to help understanding the ecology of the species and to make conservation strategies in changed environments. For this reason, the study aimed to compare and to correlate environmental factors, such as VVC, height and distance from water level, degree of disturbance and type of structure/ substrate, with the frequency that otters use shelters and marking sites along the Sapé stream (São Paulo state, Brazil) and around Canoas I hydroelectric reservoir (Paranapanema river valley, São Paulo and Paraná states, Brazil).

\section{Material and Methods}

\section{Study area}

These two studies areas were selected due to the easy accessibility, to the knowledge of otter's existence in the places and for their belonging to the same micro-basin hydrographic. The choice of the Canoas I hydroelectric reservoir derived of its relatively recent time of operation (1998) indicating that otters could be in course of adjustment to the changes of habitat yet. Sapé stream were sorted because it is a relatively preserved environment without large modifications by human activities.

The reservoir lake formed by the hydroelectric power plant Canoas I $\left(50^{\circ} 31^{\prime} \mathrm{W}\right.$ and $\left.22^{\circ} 56^{\prime} \mathrm{S}\right)$ is located in the Paranapanema Valley (middle Paranapanema micro-basin) between the cities of Cândido Mota (São Paulo State) and Itambaracá (Paraná state). The power plant has been operating since 1998 and, by using the water flow of the Paranapanema river for energy generation, it has changed the natural water system from a lotic to a semilotic environment. The reservoir occupies an area of $30.85 \mathrm{~km}^{2}$, averaging $300 \mathrm{~m}$ wide, and it has been widely used for sport fishing. Its bed is sandy with rocky outcroppings and the banks are occupied by pastures, with predominance of grasses and herbaceous plants, such as Hyparrhenia rufa (Ness) Stapf. There are also some native vegetation remnants of the seasonal semideciduous forest (Atlantic Forest domain) - Inga Wild, Erythrina crista-galli L., Psidium guajava L., Ficus L., Cassia fistula L. and Croton urucurana Baill - and degraded portions with signs of erosion (Duke Energy Brasil 2008). Tilapia (Oreochromis niloticus) farming activities were observed in three stretches of the study area. The climate of the region is subtropical, $C f b$ type, according to the Köppen-Geiger definition, with annual mean temperature of $21^{\circ} \mathrm{C}$ and $1,464.9 \mathrm{~mm}$ of rainfall.

The Sapé stream $\left(50^{\circ} 34^{\prime} 35^{\prime}\right.$ ' W and $\left.22^{\circ} 24^{\prime} 53^{\prime \prime} \mathrm{S}\right)$ is located approximately $47 \mathrm{~km}$ from the Canoas I hydroelectric power plant, in the Southeastern São Paulo state mesoregion, within the limits of the municipality of Paraguaçu Paulista (São Paulo state). The stream belongs to the middle Paranapanema river micro-basin, and covers a $39.7 \mathrm{~km}^{2}$ area, with an average width of $3 \mathrm{~m}$. At some points, native Cerrado type vegetation predominates, consisting mainly of Calophyllum brasiliense Cambess., Talauma ovate St. Hil., Cedrela odorata L. and Geonoma schottiana Mart. Other stretches are flooded, where the stream forms isolated wetlands and some marshes on the banks. The regional climate is the Cwa type, according to Köppen, with annual mean temperature and rainfall of 
$21^{\circ} \mathrm{C}$ and $1100 \mathrm{~mm}$, respectively (Casa de Agricultura de Paraguaçu Paulista - CAPP unpublished data).

\section{Methodology}

The present study was conducted between April 2008 and March 2009. Every two weeks, a $10 \mathrm{~km}$ portion was travelled by motor boat and on foot, over two days in each study area, looking for shelters and marking sites used by the otters. These sites were identified by characteristic evidences of the species, such as faeces and anal secretion deposits with characteristics shape, size and odor (Murie 1974). All sites used by the species were numbered, marked in GPS and identified with a marker ribbon.

In order to analyze the amount of vegetation cover, vertical plant cover measurements were taken on the four sides of each location (shelters and marking sites) used by otters. The methodology used was adapted from Freitas et al. (2002).

The measurements were taken $1 \mathrm{~m}$ away from the edge of the area used by the species (shelters or marking sites), so that the vegetation quantification shows the local characteristics without including the changes caused by otters, which often remove plants and prevent the development of new seedlings in their area of use (Spinola \& Vaughan 1995, Waldemarin \& Colares 2000). The VVC percentage was measured with a wooden frame $(0.5 \times 0.5 \mathrm{~m})$, divided by nylon threads into 100 equal sized-squares. The frame was placed vertically and facing the otter's usage site, at three different heights, in sequence: from zero to $0.5 \mathrm{~m}$ (squatting researcher), from 0.5 to $1 \mathrm{~m}$ tall (standing researcher with the frame at chest height), and from 1 to $1.5 \mathrm{~m}$ (standing researcher with the frame at eye level). The distance between eye and frame was standardized during all measures using the distance of extended arms to avoid that the number of squares showing vegetation to vary (Freitas et al. 2002).

The number of squares covered by leaves and branches were registered at each height (the number of covered squares represents the VVC percentage of the site). With this method was possible to identify the percentage of the location used by otters that couldn't be seen at $1 \mathrm{~m}$ away. As the measurements were taken at three different heights on each of the four sides around the use sites, $12 \mathrm{VVC}$ measurements ( 4 sides $\times 3$ heights) were obtained at each shelter and marking site. For sites marked with scat on trunks partly in the water without any nearby vegetation, the VVC was considered to be zero. The mean values of these measurements were calculated to obtain a single value for each site, and for the statistical analyses, the percentages were transformed into proportion, ranging from zero to one.

The height of each site used by the otters was measured from the water level and the distance in relation to the water was calculated by forming a $90^{\circ}$ angle from the central limit of the used area to the edge of the bank (Waldemarin 2004). The degree of disturbance was based on criteria related to human activity and adapted from the method used by Pardini \& Trajano (1999): zero represented total absence of disruption (without habitation or trails near the river), 5 represented places without habitation but with trails receiving visitors about 2 days in the week near the river $(0-20 \mathrm{~m})$ and 10 indicated highly disruptive activity (inhabited near the river and constantly used by residents) less than $10 \mathrm{~m}$ from the area used. Different use sites included within the same $50 \mathrm{~m}$ radius were represented by equal degree of disturbance values.

Only the sites continuously used by the otters in this period were considered in the analysis and the measurements were all taken in March 2009 alone, to avoid inconsistencies in the analyses at each site caused by common changes occurring in the vegetation (natural growth, flood or cut by humans), water level, and human activities during the study period.
The shelter structure types were classified into three categories: cavity amidst branches, cavity between rocks and space amidst dense vegetation (Pardini \& Trajano 1999). The substrates for marking sites were divided into seven types: grass, bared soil, rock on the bank, rock in the water, platform for fishermen, fallen trunk in the water and fallen trunk on the bank.

Every 15 days, these sites were inspected for recent signs, such as footprints, scat, anal secretion and claw marks on the banks that could indicate use by the species in this period. Faeces and secretion were removed and footprints and claw marks were erased at each inspection to prevent recounting in future inspections. At the end, the frequency of use was estimated (number of times in which recent signs were found divided by 24 - number of inspections per site) for each shelter and marking site in the two environments.

When the variances were not homogeneous, the VVC data were transformed into arcsine, and the height and distance data were $\log$-transformed $(\log +1)$ and the $t$-test was applied. If the variances remained heterogeneous after transformation, the Mann-Whitney test was used for comparisons instead of the $t$-test.

The Spearman correlation coefficient (rs) was calculated to test the relationship between the measured variables (VVC, height and distance from the water, degree of disturbance, and type of structure or substrate) with the frequency of shelter and marking site use in the stream and in the reservoir.

\section{Results}

Considering the shelters, 11 sites in use were found around the reservoir, and four in the stream. The VVC values from these sites presented a significant difference $(\mathrm{p}<0.05)$ between the two environments, with higher values around the reservoir $(94.45 \%)$. There was no significant correlation between the VVC and the frequency of shelter use in the two study areas (Table 1). Regarding the marking sites, 19 were found in use around the reservoir, and nine along the stream. The mean vertical plant cover values were not significantly different $(\mathrm{p}>0.05)$ from marking sites around the reservoir $(79.25 \%)$ and along the stream $(75.14 \%)$. A positive and significant correlation was detected between the VVC at the marking sites and their frequency of use only for the stream ( $\mathrm{rs}=0.73 ; \mathrm{p}<0.05)$.

The distance and height of shelters and marking sites in relation to the water were not significantly different between the environments, and there was also not significant correlation between height and distance and frequency of use of the sites (shelter and marking sites) used by otters in the two study areas (Table 2).

Although apparently the average degree of disturbance is higher around the reservoir (6.09) than along the stream (3.25), the statistical analyses showed no differences between the environments. Nevertheless, the correlation between disturbance and frequency of shelter use was positive and remarkable only for the reservoir ( $r s=0.84 ; \mathrm{p}<0.05$ ). This shows that, in this environment, otters make greater use of burrows near disrupted areas (Table 1). The average degree of disturbance at marking sites around the reservoir (7.53) and along the stream (3.22) was not significantly different. As with the shelters, the correlation between disturbance and frequency of markings was positive and significant only for the reservoir ( $r s=0.93 ; p<0.05)$, indicating that the otters mark more disrupted areas more effectively (Table 2 ).

As for the structure types, all the shelters along the stream were spaces amidst vegetation, while around the reservoir, most (63.64\%) were cavities between branches. The correlation of this variable with the frequency of shelter use was positive and significant only for the reservoir ( $r s=0.819 ; \mathrm{p}<0.05)$, showing the otters' preference for a 
Santos, L.B. \& Reis, N.R.

Table 1. Mean values for vertical vegetation cover, height, distance and disturbance degree, and percentages of shelter structure types and their Spearman correlations (rs) with frequency of use along the stream and around the reservoir.

\begin{tabular}{|c|c|c|c|c|}
\hline \multirow[t]{3}{*}{ Variables } & \multicolumn{2}{|c|}{ Means/percentages } & \multicolumn{2}{|c|}{ Frequency of use } \\
\hline & & & \multicolumn{2}{|c|}{ Rs } \\
\hline & Stream & Reservoir & Stream & Reservoir \\
\hline Vertical vegetation cover $(\%)$ & $69.19 \pm 22.01 *$ & $94.45 \pm 5.39 *$ & 0.31 & 0.589 \\
\hline Height (m) & $1.6 \pm 0.79$ & $2.62 \pm 2.39$ & 0.63 & 0.44 \\
\hline Distance (m) & $2.97 \pm 2.03$ & $5.57 \pm 4.23$ & 0.63 & 0.3 \\
\hline Disturbance degree & $3.25 \pm 4.72$ & $6.09 \pm 2.62$ & -0.33 & $0.84 *$ \\
\hline \multicolumn{5}{|l|}{ Structure type } \\
\hline Cavity amidst branches & $0 \%$ & $63.64 \%$ & 0 & $0.819^{*}$ \\
\hline Cavity between rocks & $0 \%$ & $9.09 \%$ & & \\
\hline Space amidst vegetation & $100 \%$ & $27.27 \%$ & & \\
\hline
\end{tabular}

$* \mathrm{p}<0.05$.

Table 2. Mean values for vertical vegetation cover, height, distance and disturbance degree, and percentages of substrate types for marking sites and their Spearman correlations (rs) with frequency of use along the stream and around the reservoir.

\begin{tabular}{|c|c|c|c|c|}
\hline \multirow[t]{3}{*}{ Variables } & \multicolumn{2}{|c|}{ Means/percentages } & \multicolumn{2}{|c|}{ Frequency of use } \\
\hline & & & \multicolumn{2}{|c|}{ Rs } \\
\hline & Stream & Reservoir & Stream & Reservoir \\
\hline Vertical vegetation cover $(\%)$ & $75.14 \pm 11.93$ & $79.25 \pm 15.46$ & $0.73 *$ & -0.23 \\
\hline Height (m) & $0.33 \pm 0.28$ & $0.6 \pm 0.58$ & -0.01 & -0.01 \\
\hline Distance (m) & $0.24 \pm 0.5$ & $0.42 \pm 2.85$ & -0.09 & -0.16 \\
\hline Disturbance degree & $3.22 \pm 3.96$ & $7.53 \pm 2.32$ & -0.27 & $0.93 *$ \\
\hline \multicolumn{5}{|l|}{ Substrate types } \\
\hline Grass & $11.11 \%$ & $36.85 \%$ & 0.079 & 0.2 \\
\hline Bare soil & $44.45 \%$ & $21.05 \%$ & & \\
\hline Stone on the bank & $11.11 \%$ & $5.26 \%$ & & \\
\hline Stone in the water & $0 \%$ & $5.26 \%$ & & \\
\hline Platform & $0 \%$ & $31.58 \%$ & & \\
\hline Trunk on the bank & $11.11 \%$ & $0 \%$ & & \\
\hline Trunk in the water & $22.22 \%$ & $0 \%$ & & \\
\hline
\end{tabular}

$* \mathrm{p}<0.05$.

given type of den in this environment (Table 1). The substrate type of the marking sites along the stream was mainly bare soil $(44.45 \%)$ and around the reservoir, grass $(36.85 \%)$ and platform for fishermen $(31.58 \%)$ (Table 2).

\section{Discussion}

The higher VVC for shelters around the reservoir corroborates with Pedroso et al. (2004) who, working around storage dams of some hydroelectric powers in Portugal, found that the existence of refuge for otters depends on the total vegetation availability in the dams. But the fact the VVC for shelters is higher around the reservoir in our study does not mean that this environment has more preserved riparian wood overall, but rather that the favored shelter sites were in a few areas with more preserved vegetation or areas with more grass or herbaceous plant cover, such as Hyparrhenia sp., which is abundant in this environment and also provides visual obstruction for the shelters. The otters and their offspring are more vulnerable when resting inside the dens, so these places require greater visual protection (Waldemarin \& Colares 2000), especially where there is intense human activity (Chanin 1985). This explains the higher VVC of the shelters around the reservoir, which has greater fishing activity than the stream.
Moreover, the greater need for shelter protection around the reservoir may be related to increased territoriality and intraspecific competition for opportunistic fish capture (fish farms) in a narrow area. It should also be considered that the greater VVC for shelters around the reservoir can be explained by the greater need for protection against climatic adversity (rain, wind and cold) in this more exposed location with little preserved vegetation. In such case, the state of conservation of the riparian forest assumes a greater importance in the immediate surroundings of the shelter than in the opposite margin of it (Kasper et al. 2008).

Otherwise, Miles (1985) states that in natural environments with less human activity, otters are not that demanding in the choice of shelters, and they may even use areas without any protection, which explains the lower vegetation cover of the stream shelters. Alike these results, Mayor-Victoria \& Botero-Botero (2010) find greater inclination of the otters to take shelter on banks with lower vegetal coverage along a river in Colombia.

With regard VVC at marking sites, there was no significant difference in the percentage of visual protection between the reservoir and the stream. Nevertheless, the positive correlation between the plant cover of the marking sites and their frequency of use along the stream supports the conclusion that the species marks the territory more often in areas with more plant cover. Similar results were observed by Spinola \& Vaughan (1995) in Costa Rica, where sites 
used for faeces deposits had greater vegetation cover than those not used. In the study conducted by Quadros \& Monteiro-Filho (2002) in the Brazilian Atlantic Forest, more scats were collected along the river with denser and better preserved riparian forest. This indicates a greater defense effort for the most suitable areas for reproduction, rest and rearing offspring.

This result can also be related with the higher population density because a less disturbed environment hosts more individuals and consequently, show more markings. Also, the greater use of marking sites with more VVC in the stream may be due to the decreased territoriality in this less disturbed environment, where food is more spread than in an equivalent stretch of the reservoir, so otters need to cover greater distances in order to find prey.

Pardini \& Trajano (1999) in the Betari river (São Paulo State) and Uchôa et al. (2004) in Salto Morato (Paraná State) observed that otters often use shelters that are higher and farther from the watercourse when there is risk of flooding. In this way, the individuals ensure higher conservation for their shelters and longer lasting scent markings. Although the water level varies more throughout the year in a small river, like the Sapé stream, than in a dammed environment (McCartney et al. 2001), this study evidenced no significant differences in height and distance from the water, for both shelters and marking sites, between the reservoir and the stream. This demonstrates that water level differences did not influence the otters' choice for dens and marking sites in terms of height and distance.

With regard to the degree of disturbance, although there is intense human activity around the reservoir, usually related to fisheries and livestock, our findings indicated no significant difference in disruption intensity around the shelters and marking sites between the environments. This is probably because the sites used by otters around the reservoir are situated in areas with smaller disruption variations (from medium to intense), and the sites used along the stream, in areas with greater disruption variation (from null to intense). This high variability between the samples increased the variation coefficient and can be impacted the statistical analyses, making it difficult to detect the significant difference between the environments.

The positive correlation between the degree of disturbance and frequency of den and marking site usage around the reservoir indicates that the animals made greater use of disrupted areas, contrary to the findings by Gori et al. (2003). This is probably due to the ease of finding food, such as fish caught in gill nets in areas with fishermen. Thus, around the reservoir, otters would find it more favorable to establish and mark territory in areas with higher degrees of disturbance. Despite some reports from inhabitants about otters being killed by fishermen, the pressure from this type of hunting is low, so the benefits gained from the proximity to fishing activity outweigh the risk of death.

This demonstrates the animal's high flexibility and adaptability to altered environments, coinciding with the results of Pedroso et al. (2004), in which have been evidenced that the reservoir has been used by otters through the year because it represented an important and permanent food source while the tributaries of the reservoir supplied shelter and supported their reproduction. On the other hand, we observed that the few human activities along the stream are usually not related to fishing and therefore do not provide greater benefits for the otters to settle in the surroundings.

As for the structure type of shelters around the reservoir, the higher percentage of dens amidst branches and the positive correlation with the frequency of use is associated with the presence of dry twigs and lianas on the banks, characteristic factors of riparian vegetation, which is more widespread in this environment due to less preserved vegetation coverage. For the stream, the fact that only burrows in spaces amidst vegetation were found can be explained by the higher availability of this structure type in more preserved riparian forest environment. Therefore, the findings from both locations indicate that otters prefer shelters formed by natural cavities that are more readily available in the environment, as reported by Pardini \& Trajano (1999) and Kasper et al. (2004).

Regarding the type of substrate for marking sites, the otters showed preference for bare soil along the stream and for grass around the reservoir. This may be due to a scarcity of conspicuous sites, such as stones on the banks, in both environments. According to Spinola \& Vaughan (1995), these would be the substrates that the species would most use for depositing faeces and anal secretion. Furthermore, the high percentage of marking sites on platforms for fishermen type substrate around the reservoir can be explained by the advantage these sites in exposing visual and scent markings, as they are located high above the water.

Actually, scat collection and elimination of other otter markings by the researchers may have influenced the deposition of new markings and faeces. Nevertheless, Quadros \& Monteiro-Filho (2002) considered that the influence of collecting faeces can be compared to the natural effects caused by rain or tidal washing, especially in tropical environments like this case.

It warrants emphasis that although the same extension $(10 \mathrm{~km})$ has been investigated in the two environments, the number of shelters and marking sites found was higher around the reservoir. There are two possible reasons for this. It may be because the otter population is larger in the reservoir than in the stream, or because the otters settle into shorter sections along the watercourse of the reservoir, where they find a greater food supply in fish farm tanks. In the stream, on the other hand, they need to travel farther to find and capture prey. Actually, the fact the number of measures collected in the shelters and marking sites around the reservoir was higher than along the stream may have influenced the results of this study more than the biotic and abiotic factors of the two environments.

According to the results, there is a greater need for visual protection of the otter shelters around the reservoir, where there are possibly more threats, territoriality and climatic adversities. In this environment they also use areas with a higher degree of disturbance, because of the opportunity to capture food from fishermen's nets, and they are more selective about their shelter structure types. Along the stream, the otters preferentially mark areas with greater VVC, probably because of the lower need to establish and evidence their territory. These observations may be related to other physical and biological differences between the environments, which were not identified in the present study. However, like the findings obtained by Kasper et al. (2008), it was apparent that the otters are somewhat adaptable to the environment they live in (natural or altered).

The optimum habitat conditions defined to the otters are: quality of vegetal coverage, availability of shelters and refuges (MacDonald \& Mason 1982, Bas et al. 1984), low aquatic pollution and human disturbance (Lunnon \& Reynolds 1991, Robitaille \& Laurence 2002) and high availability of preys (Kruuk et al. 1993, Beja 1996). Considering these factors, the otters can tolerate the reservoir's conditions because, although the three first requisites shouldn't be as much adequate as in the natural environment, they can be favoured by the opportunistic food capture in this changed environment. Pedroso et al. (2004) state in their work that the reservoirs provide food to otters through the year, on the contrary of the most watercourses associated to dams, that dry in the greater part of year, consisting in an irregular food source.

The fact that the otters use and tolerate the conditions of the reservoir doesn't mean that the implantation of this structure is benefic for the species, because the environment before the storage dam should be more positive, presenting greater habitat availability 
(in lotic system terms) with conditions of refuge and reproduction (Pedroso et al. 2004). Moreover, the species is still somewhat dependent on areas with preserved vegetation, where they can take shelter and procreate (Kasper et al. 2008).

\section{Acknowledgements}

The authors thank Capes for financial support, Fábio Fogaça, Gisele Doratti, Henrique Hortêncio, Isaac Passos Lima and Florisvaldo Bertolla for their helpful reviews on the manuscript, and especially Amadeu dos Santos and Almeriana B. Bertolla dos Santos for their invaluable assistance in the field.

\section{References}

BAS, N., JENKINS, D. \& ROTERY, P. 1984. Ecology of otters in the Northern Scotland: The distribution of otter (Lutra lutra) faeces in relation to bankside vegetation on the river Dee in summer 1981. J. Appl. Ecol. 21:507-513. http://dx.doi.org/10.2307/2403425

BEJA, P. 1996. An analysis of otter Lutra lutra predation on introduced American crayfish Procambarus clarkii in Iberian streams. J. Appl. Ecol. 33:1156-1170. http://dx.doi.org/10.2307/2404695

BERTONATTI, C. \& PARERA, A. 1994. Lobito de rio. Nuestro Libro Rojo, Fundación Vida Silvestre, Argentina. Ficha no.34. 2p.

BLACHER, C. 1992. A lontra: aspectos de sua biologia, ecologia e conservação. Ibama; UFSC, Florianópolis.

CHANIN, P. 1985. The natural history of otters. Croom Helm, Australia.

CHIARELlO, A.G., AGUIAR, L.M.S, CERQUEIRA, R., MELO, F.R., RODRIGUES, F.H.G. \& SILVA, V.M. 2008. Mamíferos ameaçados de extinção no Brasil. In Livro Vermelho da Fauna Ameaçada de Extinção (A.B.M. Machado, G.M. Drummond \& A.P. Paglia, eds.). Ministério do Meio Ambiente, Brasília, Fundação Biodiversitas, Belo Horizonte, v.2, p.681-702.

CONVENTION ON INTERNATIONAL TRADE IN ENDANGERED SPECIES OF WILD FAUNA AND FLORA - CITES. version 2008. http:// www.cites.org/eng/app/appendices.html (último acesso em 11/16/2009).

DUKE ENERGY BRASIL. Usinas. Canoas i. http://www.duke-energy.com. br/usinas/uhe_canoas_I.asp (último acesso em 05/26/2009).

EISEMBERG, J.F. \& REDFORD, K.H. 1999. Mammals of the Neotropics: The Central Neotropics. The University of Chicago Press, Chicago.

FONSECA, G.A.B., RYLANDS, A.B., COSTA, C.M.R., MACHADO, R.B. \& LEITE, Y.L.R. 1994. Livro Vermelho dos Mamíferos Brasileiros Ameaçados de Extinção. Fundação Biodiversitas, Belo Horizonte.

FREITAS, S.R., CERQUEIRA, R. \& VIEIRA, M.V. 2002. A device and standard variables to describe micro-habitat structure of small mammals based on plant cover. Braz. J. Biol. 62(4):795-800. PMid:12659030.

GORI, M., CARPANETO, G.M. \& OTTINO, P. 2003. Spatial distribution and diet of the Neotropical otter Lontra longicaudis in the Ibera Lake (northern Argentina). Acta Theriol. 48(4):495-504. http://dx.doi. org/10.1007/BF03192495

INTERNATIONAL UNION FOR CONSERVATION OF NATURE - IUCN. version 2010.2. http://www.iucnredlist.org (último acesso em 08/01/2010).

KASPER, C.B., FELDENS, M.J., SALVI, J. \& GRILLO, H.C.Z. 2004. Estudo preliminar sobre a ecologia de Lontra longicaudis (Olfers) (Carnivora, Mustelidae) no Vale do Taquari, Sul do Brasil. Rev. Bras. Zool. 21(1):65-72. http://dx.doi.org/10.1590/S0101-81752004000100012

KASPER, C.B., BASTAZINI, V.A.G., SALVI, J. \& GRILLO, H.C.Z. 2008. Trophic ecology and the use of shelters and latrines by the Neotropical otter (Lontra longicaudis) in the Taquari Valley, Southern Brazil. Iheringia, Ser. Zool. 98(4):469-474.

KRUUK, H.D., CARSS, N., CONROY, J.W. \& DURBIN, L. 1993. Otter (Lutra lutra) numbers and fish productivity in two rivers in north-east Scotland. Sym. Zool. S. 65:171-191.
LOUZADA-SILVA, D., VIEIRA, T.M., CARVALHO, J.P., HERCOS, A.P \& SOUZA, B.M. 2003. Uso de espaço e de alimento por Lontra longicaudis no lago Paranoá, Brasília, DF. Univ. Cienc. Saude. 1(2):305-316.

LUNNON, R.M. \& REYNOLDS, J.D. 1991. Distribution of the otter Lutra lutra in Ireland, and its value as an indicator of habitat quality. In Bioindicators and Environmental Management. (D.W. Jeffrey \& B. Madden, eds). Academic Press Limited, London, p.435-443.

MCCARTNEY, M.P., SULLIVAN, C. \& ACREMAN, M.C. 2001. Ecosystem impacts of large dams. IUCN/UNEP/WCD. (Background paper, no.2).

MACDONALD, S.M. \& MASON, C.F. 1982. The otter Lutra lutra in central Portugal. Biol. Conserv. 22:207-215. http://dx.doi.org/10.1016/00063207(82)90070-2

MACDONALD, S.M. \& MASON, C.F. 1987. Seasonal marking in an otter population. Acta Theriol. 32(27):449-462.

MADSEN, A.B. \& PRANG, A. 2001. Habitat factors and the presence or absence of otters Lutra lutra in Denmark. Acta Theriol. 46(2):171-179. http://dx.doi.org/10.1007/BF03192426

MAYOR-VICTORIA, R. \& BOTERO-BOTERO, A. 2010. Uso del hábitat por la nutria neotropical Lontra longicaudis (Carnivora: Mustelidae) em la zona baja del río Roble, Alto Cauca, Colombia. Bol. Cient. Mus. Hist. Nat. 14(1):121-130.

MEDINA-VOGEL, G., KAUFMAN, V.S., MONSALVE, R. \& GOMEZ, V. 2003. The influence of riparian vegetation, woody debris, stream morphology and human activity on the use of rivers by southern river otters in Lontra provocax in Chile. Oryx. 37(4):422-430. http://dx.doi. org/10.1017/S0030605303000784

MILES, H. 1985. The track of the wild otter. Elm Tree Books, London.

MURIE, O. 1974. A field guide to animal tracks. Houghton Miffin Company, Boston.

PARDINI, R. \& TRAJANO, E. 1999. Use of shelters by the neotropical river otter (Lontra longicaudis) in an Atlantic Forest stream, southeastern Brazil. J. Mammal. 80(2):600-610. http://dx.doi.org/10.2307/1383304

PARERA, A. 1993. The Neotropical river otter Lutra longicaudis population in Ibera lagoon, Argentina. IUCN Otter Specialist Group Bulletin. 8:13-16.

PEDROSO, N., SANTOS-REIS, M. \& VASCONCELOS, L. 2004. O Uso de Grandes Barragens pela Lontra no Alentejo. Rev. Biol. 22:211-224.

QUADROS, J. \& MONTEIRO-FILHO, E.L.A. 2002. Sprainting sites of the Neotropical otter Lontra longicaudis, in an atlantic forest area of southern Brazil. Mastozool. Neotrop. 9(1):39-46.

REDFORD, K.H. \& EISENBERG, J.F. 1992. Mammals of the Neotropics: the Southern Cone, Chile, Argentina, Uruguay, Paraguay. The University of Chicago Press, Chicago, v.2.

ROBITAILLE, J.F. \& LAURENCE, S. 2002. Otter, Lutra lutra, occurrence in Europe and in France in relation to landscape characteristics. Anim. Conserv. 4:337-344.

ROCHA, V.J. \& SEKIAMA, M.L. 2006. Mamíferos do Parque Estadual Mata dos Godoy. In Ecologia do Parque Estadual Mata dos Godoy (J.M.D. Torezan, org.). Itedes, Londrina, p.138-151.

ROSAS, F.C.W., COLARES, E.P., COLARES, I.G. \& SILVA, V.M.F. 1991. Mamíferos aquáticos da Amazônia brasileira. In Bases científicas para o estabelecimento de estratégias de preservação e desenvolvimento da Amazônia: fatos e perspectivas (A.L. Val, R. Figliuolo \& E. Feldsberg, eds). v.1, p.405-411.

ROSAS, F.C.W. 2004. Lontra, Lontra longicaudis (Carnivora: Mustelidae). In História natural, ecologia e conservação de algumas espécies de plantas e animais da Amazônia (R. Cintra, org.). EDUA, INPA, FAPEAM, Manaus, p.261-264.

SOLDATELI, M. \& BLACHER, C. 1996. Considerações preliminares sobre o número e distribuição espaço/temporal de sinais de Lutra longicaudis (Olfers, 1818) (Carnivora: Mustelidae) nas lagoas da Conceição e do Peri, Ilha de Santa Catarina, SC, Brasil. Biotemas. 9:38-64. 
SPINOLA, R.M. \& VAUGHAN, C. 1995. Abundancia relativa y actividad de marcaje de la nutria neotropical (Lutra longicaudis) en Costa Rica. Vida Silvestre Neotropical. 4(1):38-45.

UCHÔA, T., VIDOLIN, G.P., FERNANDES, T.M., VELASTIN, G.O. \& MANGINI, P.R. 2004. Aspectos ecológicos e sanitários da lontra (Lontra longicaudis OLFERS, 1818) na Reserva Natural Salto Morato, Guaraqueçaba, Paraná, Brasil. Cad. Biodivers. 4(2):19-28.
WALDEMARIN, H.F. 2004. Ecologia da lontra neotropical (Lontra longicaudis), no trecho inferior da bacia do rio Mambucaba, Angra dos Reis, Rio de Janeiro. Tese de Doutorado, Universidade do Estado do Rio de Janeiro, Rio de Janeiro.

WALDEMARIN, H.F. \& COLARES, E.P. 2000. Utilization of resting sites and dens by the Neotropical river otter (Lutra longicaudis) in the south of Rio Grande do Sul state, southern Brazil. IUCN Otter Specialist Group Bulletin. 17(1):14-19. 